\title{
Changes in $P$ pools over three months in two soils amended with legume residues
}

\author{
M, Alamgir ${ }^{1 *}$, P. Marschner ${ }^{2}$ \\ ${ }^{1}$ Department of Soil Science, University of Chittagong, Chittagong 4331, Bangladesh \\ ${ }^{2}$ School of Agriculture, Food and Wine, The University of Adelaide, SA 5005, Australia \\ *Corresponding author: mdalamgir@cu.ac.bd
}

\begin{abstract}
To assess the longer term effects of soil properties and residue addition on soil P pool concentrations, we added residues from three different legumes to two soils and measured the concentration of soil $\mathrm{P}$ pools over three months. The size of various $P$ pools was assessed by sequential $P$ fractionation on days $0,14,28,56,70$ and 98 . Compared to the unamended control, addition of faba bean and chickpea residues increased the concentrations of resin $\mathrm{P}$, microbial $\mathrm{P}, \mathrm{NaHCO}_{3}$-Pi temporarily whereas amendment with white lupin residues had little effect on $\mathrm{P}$ pool concentrations. The decrease in $\mathrm{NaHCO}_{3}-\mathrm{Po}$ and $\mathrm{NaOH}-\mathrm{Po}$ towards the end of the experiment coincided with an increase in NaOH-Pi in Mt. Bold soil and of HCl-Pi in Monarto soil. These temporal changes were more pronounced in soils amended with faba bean and chickpea residues than in the unamended soil or after addition of white lupin residues. The principal component analysis (PCA) plot showed that the P pool concentrations on days 0 and 98 were quite similar and differed from those on days 28, 56 and 70 suggesting clear temporal patterns. The results of this study show that the concentration of various P pools is strongly affected by soil properties such as $\mathrm{pH}$ and organic matter content and further modulated by the properties of the residues.
\end{abstract}

Keywords: $\mathrm{C} / \mathrm{P}$ ratio, legume residue, $\mathrm{P}$ fractionation, soil properties

\section{Introduction}

Appropriate management of crop residues may be an alternative to inorganic fertilizers to increase agricultural sustainability and reduce reliance on mineral fertilizers (Turmel et al. 2015). Incorporation of crop residues may allow maintaining adequate concentrations of available $\mathrm{P}$ in soil which is important from both an agronomic and an environmental point of view (Balemi and Negisho 2012). When crop residues are added, $P$ availability depends on chemical composition of crop residues and on soil properties. Decomposition of crop residues may increase $\mathrm{P}$ availability directly by net mineralization of organic $\mathrm{P}$ in the residues, and indirectly by (i) $\mathrm{H}_{2} \mathrm{CO}_{3}$ from $\mathrm{CO}_{2}$ released during decomposition which can dissolve $\mathrm{Ca}$ phosphates and (ii) organic acids released during decomposition which can exchange sorbed $\mathrm{P}$ and chelate $\mathrm{Fe}$ and $\mathrm{Al}$ thereby reducing P fixation (Easterwood and Sartain 1990). On the 
other hand, plant $\mathrm{P}$ availability may also decrease following crop residue addition due to microbial immobilization (McLaughlin and Alston 1986). The chemical composition of crop residues varies and the concentrations of $\mathrm{C}, \mathrm{N}$, lignin, cellulose, polyphenol and their ratios to $\mathrm{P}$ are regarded as predictors of decomposition rate and $\mathrm{P}$ release. Net immobilization is likely to occur if the total $\mathrm{P}$ concentration in the residues is below 2 to $3 \mathrm{~g} \mathrm{~kg}^{-1}$ and a $\mathrm{C} / \mathrm{P}$ ratio greater than 300:1, while net mineralization is likely if at $\mathrm{C} / \mathrm{P}$ $<200: 1$ (Brady and Weil 2002). Net P release is more likely in the later phases of residue decomposition due to lower microbial demand, but then also more of the $\mathrm{P}$ may be fixed because of the lower concentration of organic acid anions.

In soil, $\mathrm{P}$ moves between different organic and inorganic pools varying in availability which can be measured by sequential $\mathrm{P}$ fractionation. For a better understanding of soil $\mathrm{P}$ transformations, the size of these pools over time needs to be determined (Ochwoh et al 2015). The solubility and fixation of $P$ in soils is highly dependent on soil physicochemical properties such as pH (Barrow 1984), organic carbon content (Daly et al. 2001), texture (Toor et al. 1997), calcium carbonate content (Bertrand et al. 2003), and the concentrations of extractable $\mathrm{Fe}$ and $\mathrm{Al}$ oxides (Freese et al. 1992). In acidic soils, the predominant forms of inorganic $\mathrm{P}$ are $\mathrm{Fe}$ or $\mathrm{Al}$ phosphates whereas in neutral to alkaline soils $\mathrm{P}$ occurs as $\mathrm{Ca}$ and $\mathrm{Mg}$ phosphates (Hinsinger 2001). In acid soils, $P$ can be adsorbed on the surfaces of clay minerals or occluded in nanopores of Fe or Al oxides (Arai and Sparks 2007). In neutral to alkaline soils it can be precipitated as calcium phosphates ranging from moderately soluble dicalcium phosphate to poorly soluble hydroxyapatite (Arai and Sparks 2007). Generally soils with high concentrations of clay, amorphous oxides, allophanes and kaolinite have high P fixing capacity (Brady and Weil 2002).
In previous studies (Alamgir et al. 2012; Alamgir and Marschner 2013) we demonstrated that changes in soil $\mathrm{P}$ pools induced by plant residue addition over 42 days are affected by residue $P$ concentration and by plant part (roots or shoots) as well as by soil properties. To better understand the effect of residue addition on soil P pools and potential crop P uptake, longer term studies in soils differing in properties such as organic matter content, $\mathrm{pH}$ and texture are needed. The aim of this study was to examine the changes in P pools over three months after addition of legume residues in two soils with contrasting physical and chemical properties.

\section{Materials and Methods}

\subsection{Experimental design}

Two soils from South Australia were used in this study. The Rhodoxeralf (USDA 1999) soil was collected from a natural bush land at Monarto $\left(35^{\circ} 05^{\prime} \mathrm{S}, 139^{\circ}\right.$ $\left.04^{\prime} \mathrm{E}\right)$ and the Typic haploxeralf soil from a grassland at Mt. Bold ( $\left.35^{\circ} 04^{\prime} \mathrm{S}, 138^{\circ} 42^{\prime} \mathrm{E}\right)$. Five sub samples were collected from $0-10 \mathrm{~cm}$ depth in an area of about $20 \mathrm{~m} 2$ and mixed together to form a single composite sample. After collection, the soils were air-dried at room temperature, passed through a $2 \mathrm{~mm}$ sieve and analysed for physical and chemical properties (Table 1). Before the start of the experiment, the soils were pre-incubated for 10 days at their optimum water content for microbial activity. The optimum water content was determined in a preliminary experiment (unpublished data) by measuring cumulative respiration for 10 days at different water contents (40$90 \%$ ). Cumulative respiration was maximal at $70 \%$ of water holding capacity for Monarto and 50\% for Mt. Bold soil. This pre-incubation was used to activate the microbes and stabilize their activity before the onset of the experiment. 
Table 1. Properties of Monarto and Mt. Bold soils ( $n=3)$.

\begin{tabular}{|c|c|c|}
\hline & Monarto & Mt. Bold \\
\hline Sand $\left(\mathrm{g} \mathrm{kg}^{-1}\right)$ & 820 & 530 \\
\hline Silt $\left(\mathrm{g} \mathrm{kg}^{-1}\right)$ & 100 & 280 \\
\hline Clay $\left(\mathrm{g} \mathrm{kg}^{-1}\right)$ & 80 & 190 \\
\hline Texture & loamy sand & sandy loam \\
\hline USDA soil classification & Rhodoxeralf & Typic haploxeralf \\
\hline Bulk density $\left(\mathrm{g} \mathrm{cm}^{-3}\right)$ & 1.63 & 1.43 \\
\hline Water holding capacity $(\%)$ & 15.8 & 34.5 \\
\hline pH 1:5 $\left(\mathrm{H}_{2} \mathrm{O}\right)$ & 7.5 & 5.1 \\
\hline \multicolumn{3}{|l|}{ Total elements } \\
\hline $\mathrm{N}\left(\mathrm{g} \mathrm{kg}^{-1}\right)$ & 0.9 & 4.2 \\
\hline $\mathrm{C}\left(\mathrm{g} \mathrm{kg}^{-1}\right)$ & 7.3 & 44.1 \\
\hline $\mathrm{P}\left(\mathrm{mg} \mathrm{kg}^{-1}\right)$ & 139 & 246 \\
\hline $\mathrm{Fe}\left(\mathrm{g} \mathrm{kg}^{-1}\right)$ & 17.0 & 16.4 \\
\hline $\mathrm{Al}\left(\mathrm{g} \mathrm{kg}^{-1}\right)$ & 16.9 & 28.5 \\
\hline $\mathrm{Ca}\left(\mathrm{g} \mathrm{kg}^{-1}\right)$ & 1.5 & 0.6 \\
\hline $\operatorname{Mg}\left(\mathrm{g} \mathrm{kg}^{-1}\right)$ & 3.4 & 1.4 \\
\hline
\end{tabular}

Based on our previous studies (Alamgir et al. 2012; Alamgir and Marschner 2013), we selected three legume shoot residues differing in total $\mathrm{P}$ concentration: young faba bean (FB) (Vicia faba) (high P), mature chickpea (CP) (Cicer arietinum) (medium P) and mature white lupin (WL) (Lupinus albus) (low $\mathrm{P}$ ) which were oven-dried at $60^{\circ} \mathrm{C}$, finely ground and sieved to particle sizes between 0.25 to
$2 \mathrm{~mm}$. The residues also differed in total $\mathrm{N}$, water soluble $\mathrm{C}$ and $\mathrm{P}$ concentration which were highest in faba bean residues and lowest in white lupin residues (Table 2). The residues were added at a rate of $20 \mathrm{~g}$ residue $\mathrm{kg}^{-1}$ soil and mixed thoroughly into the preincubated soils. The calculated amounts of total C, N and $\mathrm{P}$ and water soluble $\mathrm{P}$ added with the residues are given Table 3. Twenty g soil mixed with residues was 
placed in cores of $3.7 \mathrm{~cm}$ diameter fitted with nylon mesh base and the bulk density adjusted to 1.6 and $1.4 \mathrm{~g} \mathrm{~cm}^{-3}$ for Monarto and Mt. Bold soil. The soils were incubated in the dark at $22-25^{\circ} \mathrm{C}$ for 98 days and destructively sampled on days $0,14,28,56,70$ and 98 . Thus the experiment consisted of 3 residue types, 2 soils and 6 sampling dates with 3 replicates each. There were total 144 cores with 24 cores destructively sampled at each sampling time. During incubation, soil moisture was maintained by weight with autoclaved reverse osmosis water.

Table 2. Total $\mathrm{P}, \mathrm{C}, \mathrm{N}$, water soluble $\mathrm{P}$ concentrations and $\mathrm{C} / \mathrm{N}$ and $\mathrm{C} / \mathrm{P}$ ratio of white lupin, chick pea and faba bean residues $(\mathrm{n}=3)$.

\begin{tabular}{lccccccc}
\hline Residues & $\begin{array}{c}\text { Total P } \\
\mathrm{g} \mathrm{kg}^{-1}\end{array}$ & $\begin{array}{c}\text { Water soluble } \\
\mathrm{P} \mathrm{g} \mathrm{kg}{ }^{-1}\end{array}$ & $\begin{array}{c}\text { Total C } \\
\mathrm{g} \mathrm{kg}^{-1}\end{array}$ & $\begin{array}{c}\text { Water soluble C } \\
\mathrm{g} \mathrm{kg}^{-1}\end{array}$ & $\begin{array}{c}\text { Total N } \\
\mathrm{g} \mathrm{kg}^{-1}\end{array}$ & $\begin{array}{c}\mathrm{C} / \mathrm{N} \\
\text { C/P }\end{array}$ \\
\hline White lupin & 0.6 & 0.2 & 384 & 7 & 9.7 & 40 & 640 \\
Chickpea & 1.8 & 0.6 & 418 & 60 & 21.1 & 20 & 232 \\
Faba bean & 6.6 & 5.9 & 417 & 67 & 34.5 & 12 & 63 \\
\hline
\end{tabular}

Table 3. Amounts of total $\mathrm{C}, \mathrm{N}$ and $\mathrm{P}$ and water-soluble $\mathrm{P}$ added with the white lupin, chickpea and faba bean residues at a rate of $20 \mathrm{~g} \mathrm{~kg}^{-1}$.

\begin{tabular}{lccccc}
\hline Residues & Total C & Total N & Total P & Water soluble P & Water soluble C \\
\hline White lupin & 7680 & 194 & 12 & 4 & 140 \\
Chickpea & 8360 & 422 & 36 & 12 & 1200 \\
Faba bean & 8340 & 690 & 132 & 118 & 1340 \\
\hline
\end{tabular}


Table 4. Percentage of total $\mathrm{P}$ in different $\mathrm{P}$ pools in Monarto and Mt. Bold soil on day 0 in unamended soil (control) and soil amended with chickpea (CP), faba bean (FB) and white lupin (WL) residues.

\begin{tabular}{|c|c|c|c|c|c|c|c|c|c|}
\hline Soil & Treatment & $\begin{array}{l}\text { Resin- } \\
\text { P }\end{array}$ & $\begin{array}{c}\text { Microbial- } \\
\text { P }\end{array}$ & $\begin{array}{c}\mathrm{NaHCO}_{3^{-}} \\
\mathrm{Pi}\end{array}$ & $\begin{array}{c}\mathrm{NaHCO}_{3-}^{-} \\
\text {Po }\end{array}$ & $\begin{array}{c}\mathrm{NaOH}- \\
\mathrm{Pi}\end{array}$ & $\begin{array}{l}\mathrm{NaOH}- \\
\mathrm{Po}\end{array}$ & $\begin{array}{c}\mathrm{HCl}- \\
\mathrm{Pi}\end{array}$ & $\begin{array}{c}\text { Residual- } \\
\text { P }\end{array}$ \\
\hline & & \multicolumn{8}{|c|}{$\%$ of total $\mathrm{P}$} \\
\hline \multirow[t]{4}{*}{ Monarto } & Control & 4.5 & 1.6 & 3.0 & 1.1 & 14.2 & 15.1 & 18.3 & 42.3 \\
\hline & $\mathrm{CP}$ & 8.1 & 11.9 & 5.1 & 1.6 & 12.5 & 14.0 & 12.2 & 34.6 \\
\hline & FB & 25.7 & 9.0 & 6.2 & 1.6 & 10.7 & 8.8 & 11.1 & 26.9 \\
\hline & WL & 4.6 & 2.5 & 3.4 & 1.4 & 14.7 & 14.0 & 16.6 & 42.8 \\
\hline \multirow[t]{4}{*}{ Mt. Bold } & Control & 3.4 & 1.5 & 1.6 & 7.7 & 30.0 & 13.1 & 1.4 & 41.4 \\
\hline & $\mathrm{CP}$ & 10.0 & 3.6 & 2.6 & 7.1 & 26.7 & 16.4 & 1.3 & 32.4 \\
\hline & FB & 20.3 & 2.5 & 3.5 & 5.9 & 22.7 & 14.4 & 1.0 & 29.6 \\
\hline & WL & 3.9 & 1.8 & 1.8 & 7.4 & 25.1 & 20.4 & 1.5 & 38.2 \\
\hline
\end{tabular}

\subsection{Analyses}

Physical and chemical properties were determined on air dried soils before pre-incubation. Soil $\mathrm{pH}$ was determined in a soil: water ratio 1:5. Particle size analysis was carried out by the hydrometer method (Ashworth et al. 2001). The bulk density of the soils was calculated using bulk density calculator based on the U.S. Texture Triangle (http://www.pedosphere. com/resources/bulkdensity/worktable_us.cfm). Total C and $\mathrm{N}$ of the soils and the residues were determined by dry combustion using a Leco CNS-2000, carbonates were removed from the soils by acid prior to the analysis. Total $\mathrm{Fe}, \mathrm{Al}, \mathrm{Ca}$ and $\mathrm{Mg}$ concentrations of the soils were determined by Inductively Coupled Plasma Atomic Emission Spectrometry (ICPAES) after digestion with nitric acid-perchloric acid (Olsen and Sommers 1982). Total $\mathrm{P}$ of the residues was determined after digestion with nitric acid-perchloric acid (Olsen and Sommers 1982); P in the extract was measured colormetrically by the phosphovanado-molybdate method. After the 10 day pre-incubation, cores were destructively sampled for $\mathrm{P}$ fractionation on days 0,14 , 28, 56, 70 and 98. The concentration of various P pools was determined by sequential P fractionation (Hedley et al. 1982; Tiessen and Moir 1993; Huang and Zhang 2009). The sequential extraction was carried out by shaking $1 \mathrm{~g}$ of soil (1:30 soil:solution) for $16 \mathrm{~h}$ with anion exchange resin, $0.5 \mathrm{M} \mathrm{NaHCO}_{3}, 0.1 \mathrm{M} \mathrm{NaOH}, 1$ $\mathrm{M} \mathrm{HCl}$, and again $0.1 \mathrm{M} \mathrm{NaOH}$. The second extraction with $\mathrm{NaOH}$ was carried out as Condron and Goh (1989) suggested that substantial amounts of $\mathrm{P}$ were released by $\mathrm{NaOH}$ after removal of the $1 \mathrm{M} \mathrm{HCl}$ soluble $\mathrm{P}$. The two $\mathrm{NaOH}$ extraction were done in a similar manner. The $\mathrm{NaOH}$-extractable $\mathrm{P}$ is the sum of the two $\mathrm{NaOH}$ extractions. Residual $\mathrm{P}$ was determined by digesting the soil remaining after the last step of the fractionation in $\mathrm{HNO}_{3}-\mathrm{HClO}_{4}(6: 1)$. The nature of residual $\mathrm{P}$ is not clear, but most likely includes organic and inorganic $\mathrm{P}$ not dissolved by acids and alkali used during sequential 
fractionation (Syers et al. 1967). Five $\mathrm{mL}$ of the extract from the $\mathrm{NaHCO}_{3}$ and $\mathrm{NaOH}$ fractions was acidified to $\mathrm{pH} 1.5$ to precipitate organic matter, centrifuged and the supernatant was analysed for inorganic P. Total P in the $\mathrm{NaHCO}_{3}$ and $\mathrm{NaOH}$ fractions was analysed separately by digesting $5 \mathrm{~mL}$ of the extract with $1 \mathrm{ml}$ $5 \%$ potassium persulfate at $90{ }^{\circ} \mathrm{C}$ for $16 \mathrm{~h}$ which was then analysed for total P (Huang and Zhang 2009). Organic $P$ was calculated as the difference between total $\mathrm{P}$ (after digestion) and inorganic P. For determination of microbial $\mathrm{P}$, another soil subsample was extracted with anion exchange resin with or without hexanol. Microbial $\mathrm{P}$ was calculated as the difference between the $\mathrm{P}$ concentration with and without hexanol (Kouno et al. 1995). The $\mathrm{P}$ concentration in the fractions was determined colorimetrically by the molybdenum blue method (Murphy and Riley 1962). Total P was calculated as the sum of the sequentially extracted $\mathrm{P}$ pools.

\subsection{Statistical analyses}

Three way analysis of variance (ANOVA) with the main factors residue type, soil type and sampling time (day 14-98) was carried out using GenStat for Windows 14th Edition (VSN International, Hempstead, UK, 2011). Means were compared by Tukey test at 5\% significance level. Principal component analysis (PCA) was carried out using the P pools as variables and soil properties as environmental factors for the different sampling times (Primer-E Ltd, Plymouth Marine Laboratory, Plymouth, UK).

\section{Results}

\subsection{Soil properties}

The soils used in this study differed in their physical and chemical properties (Table 1). The acidic Mt.
Bold soil had higher clay and silt contents and total C, N P and Al concentrations compared to the alkaline Monarto soil. Monarto soil had higher sand content and concentrations of total $\mathrm{Ca}$ and $\mathrm{Mg}$ than $\mathrm{Mt}$. Bold soil.

\subsection{Soil P pools}

Total $\mathrm{P}$ content did not change significantly from day 0 to day 98 in un-amended or amended soils. In the unamended soils (control), the percentage of $\mathrm{NaHCO}_{3}-\mathrm{Po}, \mathrm{NaOH}-\mathrm{Pi}$ and $\mathrm{Po}$ and residual $\mathrm{P}$ on day 0 were higher in Mt. Bold soil than in Monarto soil whereas the percentage of $\mathrm{HCl}-\mathrm{P}$ was lower (Table 4). Residual $\mathrm{P}$ was the largest pool in both soils (41.4$42.3 \%$ of total $\mathrm{P}$ ). The percentage of organic $\mathrm{P}$ was higher in Mt. Bold soil $(22.3 \%$ of total $\mathrm{P})$ than in Monarto soil (17.7 \% of total P). Residue addition increased the percentage of resin and microbial $P$ with greater changes induced by faba bean and chickpea residue addition than with white lupin residues (Table 4). The percentage of total $P$ in the different $P$ pools did not change from day 0 to day 98 in unamended or amended soils (data not shown).

In both soils the concentration of resin $\mathrm{P}$ was significantly higher when amended with high $\mathrm{P}$ residue (faba bean), than with medium (chickpea) and low (white lupin) residues (Figure 1A). During the first two weeks the resin P concentration decreased in both soils amended with residues and the decline was more prominent in Mt. Bold soil. In Mt. Bold soil the decrease in resin $\mathrm{P}$ was accompanied by a corresponding increase in microbial $\mathrm{P}$ and $\mathrm{NaHCO}_{3}$ Po whereas this was not the case for Monarto soil. After 14 days, the concentration of resin P remained stable in both soils amended with white lupin residues. When amended with chickpea and faba bean residues, the resin $\mathrm{P}$ concentration increased from day 14 to day 98 . 
Residue addition increased the microbial $\mathrm{P}$ concentration, particularly chickpea and faba bean residues with the highest concentrations on day 0 in Monarto soil and on day 98 in Mt. Bold soil (Figure 1B) The concentration of NaHCO3-Pi was highest on day 56 in both soils amended with faba bean and chickpea residues whereas the concentration of this pool was little affected by addition of white lupin residues (Figure 1C).

The $\mathrm{NaHCO}_{3}$-Po concentration was higher in Mt. Bold than in Monarto soil (Figure 1D); it fluctuated in Mt. Bold soil with the highest concentrations on day 14 and the lowest on day 98. The $\mathrm{NaHCO}_{3}-\mathrm{Po}$ concentration changed little over time in Monarto soil except for the lowest concentration on day 98 in the residue amended soil.

The concentration of both organic and inorganic $\mathrm{NaOH}-\mathrm{P}$ pools was higher in Mt. Bold than in Monarto soil (Figure 1E and 1F). In Monarto soil, addition of faba bean residues increased the concentration of $\mathrm{NaOH}-\mathrm{Pi}$ compared to the unamended soil whereas the other residues had no effect (Figure 1E). In Mt. Bold soil, the NaOH-Pi concentration was higher on days 0 and 98 than on the other sampling days except for the soil amended with faba bean residues where the NaOH-Pi concentration was also high on day 14 .

Addition of chickpea and faba bean residues increased the concentration of $\mathrm{NaOH}-\mathrm{Po}$ compared to the unamended control in both soils whereas amendment with white lupin residues increased the concentration of this pool only in Mt. Bold soil and only on days 0 and 28 (Figure 1F). There was little change in the concentration of $\mathrm{NaOH}-\mathrm{Po}$ over time in the Monarto soil except for a peak on day 56 when amended with faba bean residues. In Mt. Bold soil, the $\mathrm{NaOH}-\mathrm{Po}$ concentration increased from day 0 to day 28 or 56 and then decreased to day 98 . The decrease in $\mathrm{NaOH}$ Po concentration from day 70 to 98 was accompanied by an increase in $\mathrm{NaOH}$ Pi concentration in this period.

The HCl-Pi concentration was higher in Monarto than in Mt. Bold soil (Figure 1G). Residue addition had no effect on the concentration of HCl-Pi in either soil. The size of this pool did not change over time in Mt. Bold soil. In Monarto soil, the HCl-Pi concentration decreased from day 0 to day 14 and increased again from day 70 to day 98 .

The residual $\mathrm{P}$ concentration was higher in Mt. Bold than in Monarto soil (Figure 1H) and in both soils the concentration of this pool increased from day 0 to day 28 or 56 and then decreased. Residue addition increased the residual $\mathrm{P}$ concentration only temporarily. In Monarto soil, the residual $\mathrm{P}$ concentration was higher than in the unamended control on day 28 when amended with chickpea residues and on day 56 in soil amended with white lupin residues. In Mt. Bold soil, addition of faba bean residues increased the residual $\mathrm{P}$ concentration on day 28.

The PCA plot based on the soil P pools showed a clear separation between the control soils and those amended with white lupin residues on the left and the soils amended with faba bean and chickpea on the right side in both soils with higher concentrations of all P pools in the latter (Figure 2). There is also a change in $\mathrm{P}$ pools over time, with the samples taken on days 0 and 98 separate from those from day 28, 56 and 70. This temporal change was generally more pronounced in the soils amended with faba bean and chickpea residues than in the unamended control and the soil with white lupin residues. The main P pools on days 0 and 98 were $\mathrm{NaOH}-\mathrm{Pi}$ and microbial biomass in both soils but there also were some differences among the soils. On days 0 and 98 , high concentration of $\mathrm{HCl} \mathrm{Pi} \mathrm{were} \mathrm{found} \mathrm{in} \mathrm{Monarto}$ soil whereas the resin $\mathrm{P}$ concentration was high in Mt. Bold soil. 


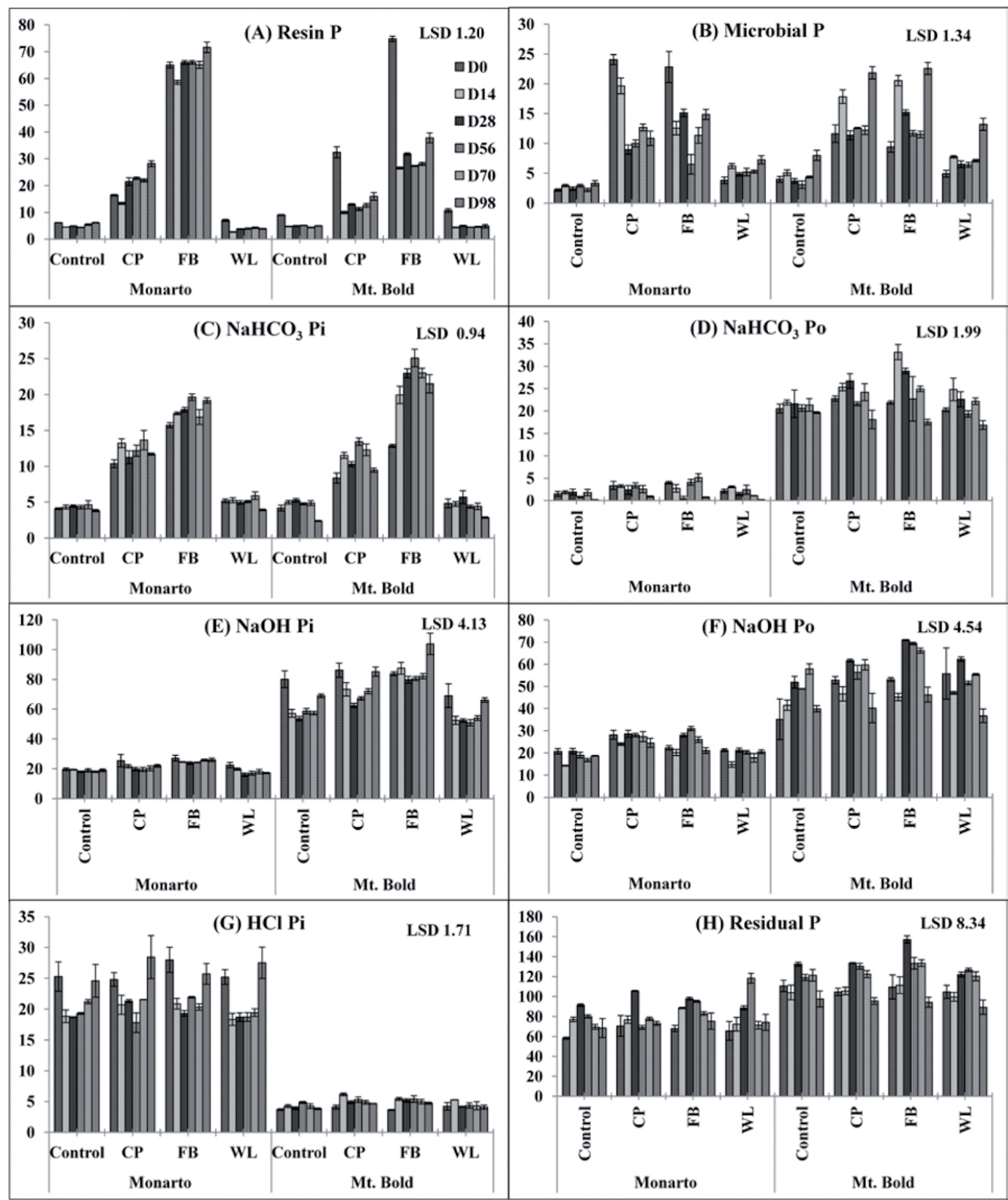

Figure 1. Concentrations of different $P$ pools in unamended soil (control) and soil amended chickpea (CP), faba bean (FB) and white lupin (WL) residues on days $0,14,28,56,70$ and 98 (n=3). (A) resin $\mathrm{P}$, (B) microbial $\mathrm{P}$, (C) $\mathrm{NaHCO}_{3} \mathrm{Pi}$, (D) $\mathrm{NaHCO}_{3} \mathrm{Po}$, (E) NaOH Pi, (F) NaOH Po, (G) HCl Pi and (H) residual $\mathrm{P}$ (n=3, error bar represents standard deviation). 

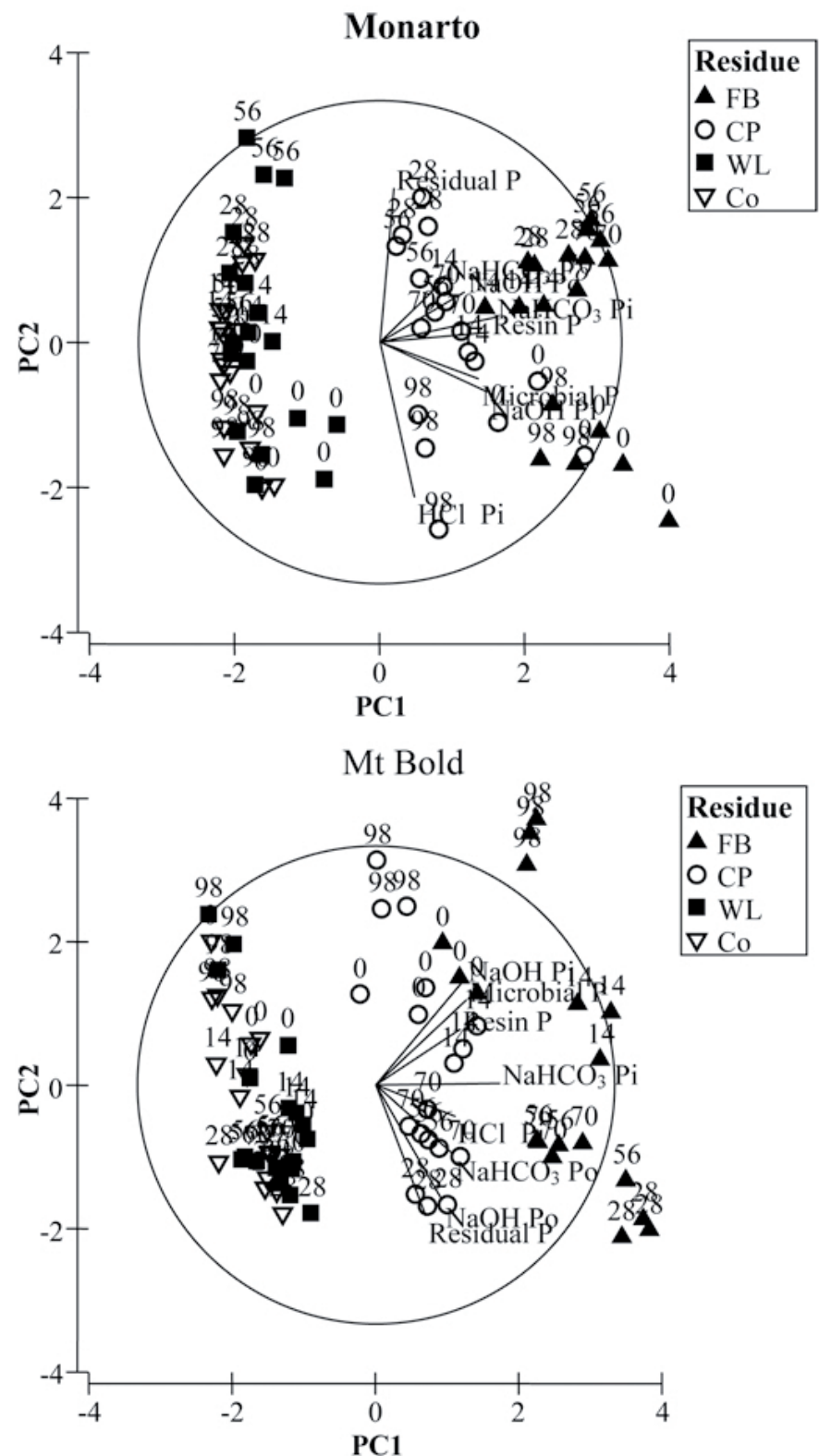

Figure 2. Principal component analysis based on P pool concentrations on days $0,14,28,56$ and 98 in Monarto and Mt. Bold soil amended with faba bean, chickpea and white lupin residues or the unamended control $(n=3)$. Values next to the symbols indicate sampling time, vectors the concentration of the P pools 


\section{Discussion}

The results of the study indicate that residue amendment changes the size of the soil $\mathrm{P}$ pools and that there is also a distinct temporal pattern in the $\mathrm{P}$ pool concentration over the 98 day incubation period which differed between residue and soil type. The high initial concentrations of $\mathrm{NaHCO}_{3}-\mathrm{Po}, \mathrm{NaOH}-\mathrm{Pi}$ and $\mathrm{Po}(\mathrm{Fe}$ and $\mathrm{Al}$ bound $\mathrm{P}$ ) and total $\mathrm{P}$ in the acidic Mt. Bold soil can be explained by its high organic $\mathrm{C}$ and $\mathrm{Al}$ concentrations and low $\mathrm{pH}$. The high concentration of $\mathrm{HCl}-\mathrm{Pi}$ (Ca bound $\mathrm{P}$ ) in Monarto soil is probably due to the high $\mathrm{Ca}$ concentration in this soil and its high pH (Arai and Sparks 2007). Several other studies also reported that size and forms of $\mathrm{P}$ in soil depends on the soil properties such as $\mathrm{pH}$, organic matter content, soil texture, clay content and even clay mineralogy (Tiessen et al. 1984; Hinsinger 2001; Zhu et al. 2013; Chatterjee et al. 2014). However, we show for the first time the temporal changes in $\mathrm{P}$ pools over 3 months and how this is modulated by residue addition and soil properties.

The decrease in $\mathrm{NaHCO}_{3}-\mathrm{Pi}$ and $\mathrm{NaHCO}_{3}-\mathrm{Po}$ concentration and the increase in $\mathrm{NaOH}-\mathrm{Pi}$ and $\mathrm{HCl}-$ Pi concentration over time suggest the transformation of labile inorganic and organic $\mathrm{P}$ into non-labile inorganic $\mathrm{P}$ by $\mathrm{P}$ sorption or fixation. Mineralization of $\mathrm{NaHCO}_{3}$-Po can contribute to an increase in resin $\mathrm{P}$ (Zheng et al. 2002), but this was not observed in the present study.

The $\mathrm{NaOH}$ pool represents organic or inorganic $\mathrm{P}$ associated with iron and aluminium (Hedley et al. 1982; Tiessen and Moir 1993). In Monarto soil, the concentration of this pool changed little over time. However, this does not mean that little P movement (flux) occurred in and out of this pool, it could also be that influx was equal to efflux. In Mt Bold soil on the other hand, the concentration of this pool was high at the start and the end of the experiment, but was lower on days 28 to 70 . This suggests that $\mathrm{P}$ moved from this pool in the early stages of the experiment. The increase in $\mathrm{NaOH}-\mathrm{Pi}$ (representing $\mathrm{P}$ associated with $\mathrm{Fe}$ and $\mathrm{Al}$ ) towards the end of the experiment in Mt. Bold soil was accompanied by a decrease in $\mathrm{NaOH}-\mathrm{Po}$ and $\mathrm{NaHCO}_{3}$-Po suggesting mineralization of organic $\mathrm{P}$ and transformation into the more stable $\mathrm{NaOH}-\mathrm{Pi}$. In Monarto soil, some the P released from the organic $\mathrm{P}$ in the $\mathrm{NaHCO}_{3}$ and $\mathrm{NaOH}$ fractions may also have contributed to the increase in $\mathrm{HCl}-\mathrm{Pi}$ ( $\mathrm{P}$ associated with $\mathrm{Ca}$ ) to day 98 . Despite differences in temporal changes in $\mathrm{P}$ pools between Monarto and Mt. Bold, the PCA showed that in both soils the P pool concentrations on day 0 and 98 were quite similar and differed from the concentrations on days 28,56 and 70 suggesting clear temporal patterns and a limited effect of residue addition on these patterns in the long term (Figure 2). Nevertheless, the temporal changes were more pronounced in the soils amended with faba bean and chickpea residues indicating that addition of residues with medium or high $\mathrm{P}$ concentration affects the dynamics among the soil $\mathrm{P}$ pools. The decrease in organic $\mathrm{P}$ pools over time was followed by an increase in $\mathrm{NaOH}-\mathrm{Pi}$ but also of microbial biomass $\mathrm{P}$ suggesting that some of the $\mathrm{P}$ mineralized was taken up by the soil microbes in the later stages of the experiment. Days 0 and 98 were also characterized by high concentrations of HCl-Pi in Monarto soil and resin $\mathrm{P}$ in Mt. Bold soil suggesting that $\mathrm{P}$ is maintained in plant available form in Mt. Bold soil whereas it is converted into the less labile $\mathrm{HCl} \mathrm{Pi}$ in Monarto soil. However, HCl-Pi can be mobilized by plant roots and contribute to plant P uptake (Mat Hassan et al. 2012).

\section{Conclusions}

This study showed that although the temporal pattern in the P pool concentration differed between residue and soil type, the long term effect of residue addition 
on $\mathrm{P}$ pool concentrations was limited. Studies with $32 \mathrm{P}$ labelled residues and combining 31P Nuclear magnetic resonance spectroscopy or X-ray absorption spectroscopy with chemical fractionation are needed to precisely quantify the fluxes of $\mathrm{P}$ in soil.

\section{Acknowledgements}

The project was conducted with financial support from the Australian Research Council. Md Alamgir received an Endeavour Postgraduate Award to conduct this study.

\section{References}

Alamgir. M, Marschner, P. 2013. Changes in phosphorus pools in three soils upon addition of legume residues differing in carbon/phosphorus ratio. Soil Research. 51, 484-493.

Alamgir, M., McNeill, A., Tang, C., Marschner, P. 2012. Changes in soil $\mathrm{P}$ pools during legume residue decomposition. Soil Biology and Biochemistry. 49, 70-77.

Arai Y, Sparks DL 2007. Phosphate reaction dynamics in soils and soil components: A multiscale approach. In: LS Donald (ed). Advances in agronomy, Vol. 94, Academic Press, Waltham, MA, pp. 135-179.

Ashworth, J., Keyes, D., Kirk R., Lessard, R 2001. Standard procedure in the hydrometer method for particle size analysis. Communications in Soil Science and Plant Analysis. 32, 633-642.

Balemi. T., Negisho, K. 2012. Management of soil phosphorus and plant adaptation mechanisms to phosphorus stress for sustainable crop production: a review. Journal of Soil Science and Plant Nutrition. 12, 547-562.
Barrow, N. 1984. Modelling the effects of $\mathrm{pH}$ on phosphate sorption by soils. Journal of Soil Science. 35, 283-297.

Bertrand, I., Holloway, R.E., Armstrong, R.D., McLaughlin, M.J. 2003. Chemical characteristics of phosphorus in alkaline soils from southern Australia. Soil Research. 41, 61-76.

Brady, N.C, Weil, R.R. 2002. The nature and properties of soils, Prentice Hall, Englewood Cliffs, NJ, $960 \mathrm{p}$.

Chatterjee, D., Datta, S.C., Manjaiah, K.M. 2014. Fractions, uptake and fixation capacity of phosphorus and potassium in three contrasting soil orders. Journal of Soil Science and Plant Nutrition,.14, 640-656.

Condron, L., Goh, K. 1989. Effects of long-term phosphatic fertilizer applications on amounts and forms of phosphorus in soils under irrigated pasture in New Zealand. Journal of Soil Science. 40, 383-395.

Daly, K., Jeffrey, D., Tunney, H. 2001. The effect of soil type on phosphorus sorption capacity and desorption dynamics in Irish grassland soils. Soil Use and Management. 17, 12-20.

Easterwood, G.W., Sartain, J. 1990. Clover residue effectiveness in reducing orthophosphate sorption on ferric hydroxide coated soil. Soil Science Society of America Journal. 54, 1345-1350.

Freese, D., Zee, S., Riemsdijk, W.H. 1992. Comparison of different models for phosphate sorption as a function of the iron and aluminium oxides of soils. Journal of Soil Science. 43, 729-738.

Hedley, M.J., Stewart J.W.B., Chauhan, B.S. 1982. Changes in inorganic and organic soil-phosphorus fractions induced by cultivation practices and by laboratory incubations. Soil Science Society of America Journal. 46, 970-976. 
Hinsinger, P. 2001. Bioavailability of soil inorganic $\mathrm{P}$ in the rhizosphere as affected by root-induced chemical changes: a review. Plant and Soil. 237, 173-195.

Huang, X., Zhang, J. 2009. Neutral persulfate digestion at sub-boiling temperature in an oven for total dissolved phosphorus determination in natural waters. Talanta. 78, 1129-1135.

Kouno, K., Tuchiya, Y., Ando, T. 1995. Measurement of soil microbial biomass phosphorus by an anion exchange membrane method. Soil Biology \& Biochemistry. 27, 1353-1357.

Mat Hassan. H., Marschner, P., McNeill, A., Tang, C. 2012. Grain legume pre-crops and their residues affect the growth, $\mathrm{P}$ uptake and size of $\mathrm{P}$ pools in the rhizosphere of the following wheat. Biology and Fertility of Soils. 48, 775-785.

McLaughlin, M., Alston, A. 1986. The relative contribution of plant residues and fertilizer to the phosphorus nutrition of wheat in a pasture cereal system. Soil Research. 24, 517-526.

Murphy, J., Riley, J.P. 1962. A modified single solution method for the determination of phosphate in natural waters. Analytica Chimica Acta. 27, 3136.

Ochwoh, VA., Nankya, E., Claassens, AS., Steenkamp, CJ. 2015. Transformations and distributions of the applied and native phosphorus into different phosphorus pools in incubated Rustenburg and Loskop soils. International Journal of Agriculture Innovations and Research. 3, 1571-1578.

Olsen, S., Sommers, L. 1982. Phosphorus. In: AL Page, RH Miller, DR Keeney (Eds). Methods of soil analysis, Vol. 2, ASA and SSSA, Madison, WI, pp. 403-430.
Syers, J.K., Williams, J.D.H., Campbell, A.S., Walker, T.W. 1967. The significance of apatite inclusions in soil phosphorus studies. Soil Science Society of America Proceedings. 31, 752-756

Tiessen, H., Moir, J.O. 1993. Characterization of available $\mathrm{P}$ by sequential extraction. In: $\mathrm{M}$ $\mathrm{R}$ Carter (ed). Soil sampling and methods of analysis, Lewis Publication, Chelsea, MI, pp $75-86$.

Tiessen, H., Stewart, J.W.B.,Cole, C.V. 1984. Pathways of phosphorus transformations in soils of differing pedogenesis. Soil Science Society of America Journal. 48, 853-858.

Toor. G., Bahl G., Vig, A. 1997. Pattern of P availability in different soils as assessed by different adsorption equations. Journal of the Indian Society of Soil Science. 45, 719-723.

Turmel, M.S.,Speratti, A. Baudron, F., Verhulst, N., Govaerts, B. 2015. Crop residue management and soil health: A systems analysis. Agricultural Systems.134, 6-16.

USDA. 1999. Soil Taxonomy: a basic system of soil classification for making and interpreting soil surveys. Version 2. Agriculture Handbook No. 436, USDA Natural Resources Conservation Service, Washington, DC.

Zheng, Z., Simard, R.R., Lafond, J., Parent, L.E. 2002. Pathways of soil phosphorus transformations after 8 years of cultivation under contrasting cropping practices. Soil Science Society of America Journal. 66, 999-1007.

Zhu, Y., Zhang, R., Wu, F., Qu, X., Xie, F., Fu, Z. 2013. Phosphorus fractions and bioavailability in relation to particle size characteristics in sediments from Lake Hongfeng, Southwest China. Environmental Earth Sciences. 68, 1041-1052. 